Silva da Silva, J., dos Santos Braga, B.S., da Silva Costa, J., Schlemmer Brasil, L., Lobato de Oliveira-Bahia, V.R., Pimentel Leal, R., Felipe Marques, J.R., \& de Araújo Guimarães, D.A. (2021). Sexual dimorphism in the turtle Kinosternon scorpioides (Testudines: Kinosternidae) from Marajó Island, Brazilian Amazon. Revista de Biología Tropical, 69(2), 601-614. https://doi.org/10.15517/rbt. v69i2.42834

https://doi.org/10.15517/rbt.v69i2.42834

\title{
Sexual dimorphism in the turtle Kinosternon scorpioides (Testudines: Kinosternidae) from Marajó Island, Brazilian Amazon
}

\author{
Joilson Silva da Silva ${ }^{1}$ \\ Brenda Stefany dos Santos Braga ${ }^{1}$ \\ Juliane da Silva Costa ${ }^{1 *}$ \\ Leandro Schlemmer Brasil ${ }^{1}$ \\ Verônica Regina Lobato de Oliveira-Bahia ${ }^{1}$ \\ Relionan Pimentel Leal ${ }^{2}$ \\ José Ribamar Felipe Marques ${ }^{2}$ \\ Diva Anélie de Araújo Guimarães ${ }^{1}$
}

1. Institute of Biological Sciences, Universidade Federal do Pará, Belém, Pará, Brazil; jss26joilson@gmail.com, brenda.braga@icb.ufpa.br, jsc.zootecnista@gmail.com (*Correspondence), leandrobrasilecologia@gmail.com, veronicaoliveirabahia@gmail.com,diva@ufpa.br

2. Empresa Brasileira de Pesquisa Agropecuária, Embrapa Amazônia Oriental, Belém, Pará, Brazil; relionan.leal@gmail.com,jrrffm@me.com

\author{
Received 08-VII-2020. C Corrected 06-II-2021. Accepted 22-IV-2021.
}

\begin{abstract}
Introduction: Morphometrics analysis is an efficient and low-cost technique used in studies of sexual dimorphism in turtles. Kinosternon scorpioides scorpioides, scorpion mud turtle, has a wide phenotypic variation, depending on the area of its occurrence. Objective: The objective of this work was to identify the anatomical sexual difference of K. s. scorpioides, adults and hatchlings, through morphometric analysis; and relate the weights of adult animals to environmental factors (temperature and rainfall) in Marajó Island, Brazil. Methods: The sample collection was carried out from March to September 2018, covering both the rainy season (January to July) and the dry season (August to December). For the biometric analysis, 95 adults and 21 hatchlings were used, in which the length and width of the carapace and plastron, height of the shell, and weight were measured (adults only). For the geometric morphometry analysis, 21 adults and 13 hatchlings were used, in which 27 coordinates of anatomical landmarks were inserted in each image of the carapace and 11 in the plastron. Hatchlings were sexed by histology which was enabled by the identification of the ovaries and testicles. Results: The results showed the existence of dimorphism in adults. The plastron and height were higher in females, which had a more rounded carapace than males. This characteristic may be related to the species' sexual strategy, where males impose copulation. Histologically, it was possible to identify the ovaries and testicles in the hatchlings, but there was no anatomical sexual difference, despite the tendency to differentiate in the analysis of carapace PCA. Conclusions: Sexual dimorphism in K. s. scorpioides may play an important role on its reproductive behavior, which is synchronized with environmental events. This fact suggests that the reproductive strategies of this species would be severely affected by changes in the ecosystem.
\end{abstract}

Key words: biometrics; geometry morphometrics; scorpion mud turtle; sexual difference; turtles. 
The turtles or Testudines are represented by 356 species, and considering the subspecies, they total 478 modern taxa, divided into 13 families (Rhodin et al., 2017). Of this total, 20 $\%$ are found in South America (Souza, 2004; Ferreira-Júnior, 2009). Thirty-six species are known in Brazil (Costa \& Bérnils, 2018), out of which 17 terrestrial species have been identified in the Brazilian Amazon, 15 aquatic and two terrestrial species.

Studies on the biological processes related to the growth, change in the size, shape and body pattern of turtles, can be carried out through morphometric analysis of the carapace and plastron. This technique has been applied to distinguish morphological variations by anatomical landmarks (Monteiro \& Reis, 1999), proving to be accurate for phylogenetic studies and sexual differentiation of these animals (Valenzuela, Adams, Bowden, \& Gauger, 2004; Depecker, Berge, Penin, \& Renous, 2006; Ferreira-Júnior, Treichel, Scaramussa, \& Scalfoni, 2011; Sönmez, Bağda, Candan, \& Yilmaz, 2019). Morphological analyses allow researchers to precisely identify the shape and size of biological organisms, allowing the observation of their morphological changes (Van Der Molen, Martínez-Abadía, \& González, 2007). It has as an advantage of increasing the feasibility of collecting samples, as only an analysis of the photograph of the animal is necessary (Lyra, Hatadani, Azeredo-Espin, \& Klaczko, 2010). It is important to understand that most of the techniques used in sexing chelonian hatchlings are largely impractical and invasive, even requiring to slaughter the animal (Valenzuela et al., 2004). Therefore, it is necessary to apply non-invasive techniques, to differentiate the sex of the hatchlings. Sexing is a useful tool in management practices in the wild or captivity, enabling the correct intervention for the reintroduction and release of animals, or in the formation of groups.

The scorpion mud turtle (Kinosternon scorpioides scorpioides) is geographically distributed from Panama to Argentina and inhabits permanent, semi-permanent and temporary aquatic environments (Iverson, 2010; Berry
\& Iverson, 2011). This species is one of the smallest turtles of the Amazon forest, measuring from 18 to $27 \mathrm{~cm}$ in length (Vogt, 2008). Its conservation status in the Brazilian territory is categorized as least concern (Vogt et al., 2015), despite it being the only species of the Kinosternidae family occurring in Brazil (Viana, Santos, \& Antunes, 2015). It is severely exploited by illegal consumption and trade in many places (Ferrara et al., 2016), especially in Marajó island, State of Pará, Brazil (Cristo, Baía-Júnior, Silva, Marques, \& Guimarães, 2017). In addition, there are few conservation and management programs for this species. This animal is well adapted to captive conditions; however, it is necessary to expand the knowledge about its nutritional requirements and management (Costa et al., 2017). In this instance, there is little information of the aspects regarding the reproductive biology of the free-living species. Nevertheless, it is known that they copulate on land and in shallow waters. Their nests are found at the base of the roots of shrubs, away from water bodies (Ferrara et al., 2016). Sex is determined by the temperature of incubation during embryonic development (Ewert \& Nelson, 1991; RuedaAlmonacid et al., 2007), and sexual maturity is attained when the animal reaches 2.8 to 5 years old (Vogt, 2008).

The phenotypic difference between adult males and females, raised in captivity, is related to body size, plastron shape, weight, tail size and pigmentation in the male's head (Castro, 2006). The adult female measures an average of $15.26 \mathrm{~cm}$ in length and $430.08 \mathrm{~g}$ in weight, and the male $14.79 \mathrm{~cm}$ and 314.05 $\mathrm{g}$, respectively (Castro, 2006). Generally, the first nesting occurs, when the female reaches $10 \mathrm{~cm}$ in carapace length (Barreto, Lima, \& Barbosa, 2009). In males, sexual maturity is reached at $10 \mathrm{~cm}$ (Barreto et al., 2009) to 13.2 $\mathrm{cm}$ in carapace length (Vogt, 2008). However, a variation in the body size has been found in the wild, where males may be larger or smaller in relation to females (Berry \& Iverson, 2011). Hatchling turtles in captivity are on average 2.6 $\mathrm{cm}$ long and weigh $2.8 \mathrm{~g}$ (Costa et al., 2017). 
They do not show any apparent sexual dimorphism until they reach 20 months of age (9.4 $\mathrm{cm}$ in length), when there is an increase in the tail and the presence of pigmentation on the head of the males (Castro, 2006).

Thus, the main objective of this research was to identify the sexual morphological difference of $K$. s. scorpioides through the morphometric analysis of adult animals and hatchlings turtles, in addition to relating the weight measurements of adult animals to environmental factors (temperature and rainfall) in Marajó island, Pará, Brazil.

\section{MATERIALS AND METHODS}

Data collection: Samples from 95 wild adults $K$. s. scorpioides, for traditional morphometrics (biometrics) and weight analysis, were collected in Cachoeira do Arari, Mesoregion of Marajó island, Pará, Brazil, specifically in Guajarás farm $\left(0^{\circ} 37^{\prime} 7.50^{\prime \prime} \mathrm{S} \&\right.$ $\left.48^{\circ} 58^{\prime} 59.68^{\prime \prime} \mathrm{W}\right)$ (Fig. 1). The animals were captured manually in the wild, followed by release. No anesthetic was used, with a short physical containment time. In addition, photoidentification technique of the animal's head was used for records, as it has different marks, avoiding recapture. The meteorological data were obtained from the National Meteorological Institute of Brazil. The annual temperature, rainfall and humidity, for 2018, were: $26.16 \pm$ $4.15{ }^{\circ} \mathrm{C}, 987.8 \pm 9.66 \mathrm{~mm}$, and $78.59 \pm 13.00$ $\%$ for the rainy season (January to July), and $27.61 \pm 3.33{ }^{\circ} \mathrm{C}, 56.1 \pm 4.35 \mathrm{~mm}$, and $72.58 \pm$ $10.02 \%$ for the dry season (August to December), respectively (Moraes, Costa, Costa, \& Costa, 2005). The research was carried out between March to September 2018, 48 females and 25 males were captured in the rainy season, and 13 females and nine males in the dry season. The reason that few animals were captured during the dry season, is due to the behavior of this species, which remains in estivation buried in the soil, and it is hardly observed in the fields (Berry \& Iverson, 2011; Cristo et al., 2017).

Samples from 21 adults and 13 hatchling turtles, for geometric morphometry study, were collected from the scientific research breeding facility of Empresa Brasileira de Pesquisa Agropecuária - Embrapa Amazônia Oriental (License number 7310/2014-SEMAS-PA), located in Salvaterra, Marajó island, Pará, Brazil, (042’26.90” S \& 48³3'34.70” W) (Fig. 1). In addition to the 13 samples, more eight hatchlings were also obtained for biometry, a total of 21 animals. Hatchlings were sexed by histological analysis of the gonads. The testicles and ovaries were fixed in Bouin's solution and preserved in $70 \%$ alcohol. The samples were dehydrated in an increasing ethanolic solution (70, 80, 90 and $100 \%$ ), diaphanized in xylol and included in paraffin. Posteriorly, histology sections $5 \mu \mathrm{m}$ were stained with Hematoxylin and Eosin, and the slides were analyzed with optical microscopy.

The research performed were approved by the Chico Mendes Institute for Biodiversity Conservation (ICMBio-SISBIO 59314-1), the Ethics Committee for Animals Research - Universidade Federal do Pará (Authorization number CEUA 7749240817), and the Ethics Committee for Use of Animals - Embrapa (Authorization number 001-2016).

Morphometrics: Ninety-five adults scorpion mud turtle (61 females and 34 males) and 21 hatchlings (17 females and four males) were used for biometric analysis. Ten anatomical points were identified on the animals, and the following morphometric characters were analyzed (Castro, 2006; Costa et al., 2017): 1- Rectilinear carapace length (CL); 2- Rectilinear carapace width $(\mathrm{CW})$; 3- Rectilinear plastron length (PL); 4- Rectilinear plastron width (PW); 5- Shell height (HCP), as shown in Fig. 2.

Adult animals were measured with a 300 mm pachymeter, $0.02 \mathrm{~mm}$ scale (MTX $\left.{ }^{\circledR}\right)$, and the hatchlings with a $150 \mathrm{~mm}$ pachymeter, $0.02 \mathrm{~mm}$ scale (Starfer). A digital scale (FWB ${ }^{\circledR}$ Model 41375), range from $1 \mathrm{~g}$ to $7 \mathrm{~kg}$, was used to weigh adults. Weights of the hatchlings was not obtained, because the samples were analyzed after the removal of the animal organs. 

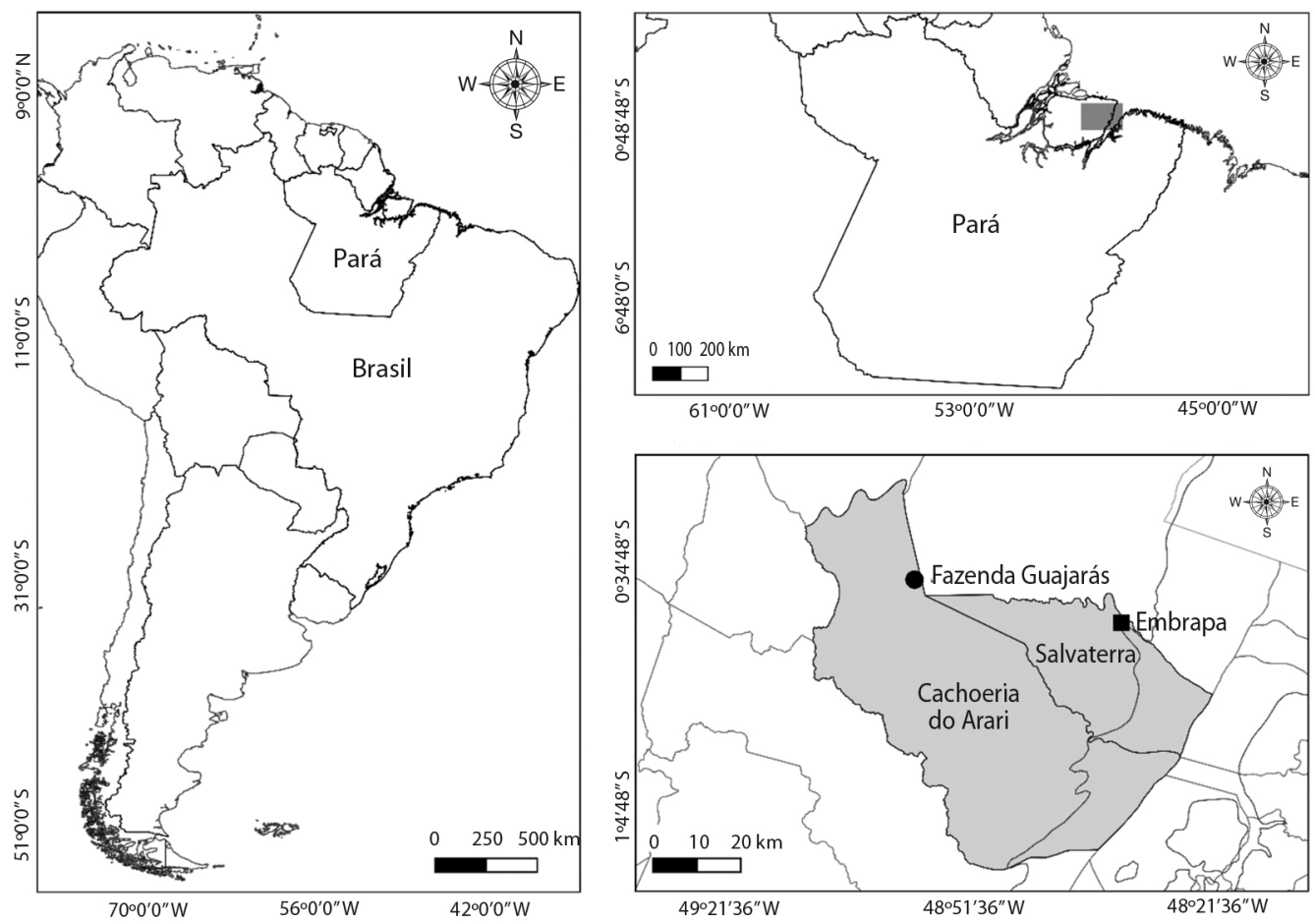

Fig. 1. Arari microregion in Marajó island, Pará, Brazil. Grey area for the municipality of Cachoeira do Arari and Salvaterra, places of samples collection of $K$. scorpioides scorpioides.

Twenty-one adults (11 females and 10 males) and 13 hatchlings (nine females and four males) scorpion mud turtles were selected, by the more visible intersections of the shields, for geometric morphometry analysis. The reference points were measured according to the intersections of the vertebral and internal shields of the carapace (Valenzuela et al., 2004; Mendes, 2017). Twenty-seven coordinates of anatomical landmarks (Ferreira-Júnior et al., 2011; Mendes, 2017) were inserted in each image of the carapace, and 11 in the plastron (Fig. 3). This study used type-1 anatomical landmarks (juxtapositions of different tissues), and the reference points were marked with a TPSDIg2 software, and analyzed in the MorphoJ software (Klingenberg, 2011).

The carapace and plastron of the scorpion mud turtle were recorded with an f/2.8 aperture digital camera (Canon Eos Rebel T5) equipped with a $60 \mathrm{~mm}$ macro lens, mounted on a level tripod, at a focal distance of $15 \mathrm{~cm}$ in height from the object (Domingues, 2015; Mendes, 2017). A $30 \mathrm{~cm}$ ruler was used for scale reference. Posteriorly, files were imported into the tpsUtil software, the distortion generated by unwanted curves was removed statistically, and converted the JPEG-format photographs into TPS (Haas, 2011).

Statistical analysis: First, one permutational multivariate analysis of variance test (PERMANOVA) was generated, and later one t-test for each variable, both using a Bonferroni alpha of 0.025 to avoid type I error. The PERMANOVA was generated with a biometric data matrix using Euclidean distance (Anderson, 2005), separately, differentiated the males from the females. The homogeneity of variance for the t-test was tested with the Levene test (Vieira, 1997). Pearson's correlation coefficient was applied to check the degree of association 


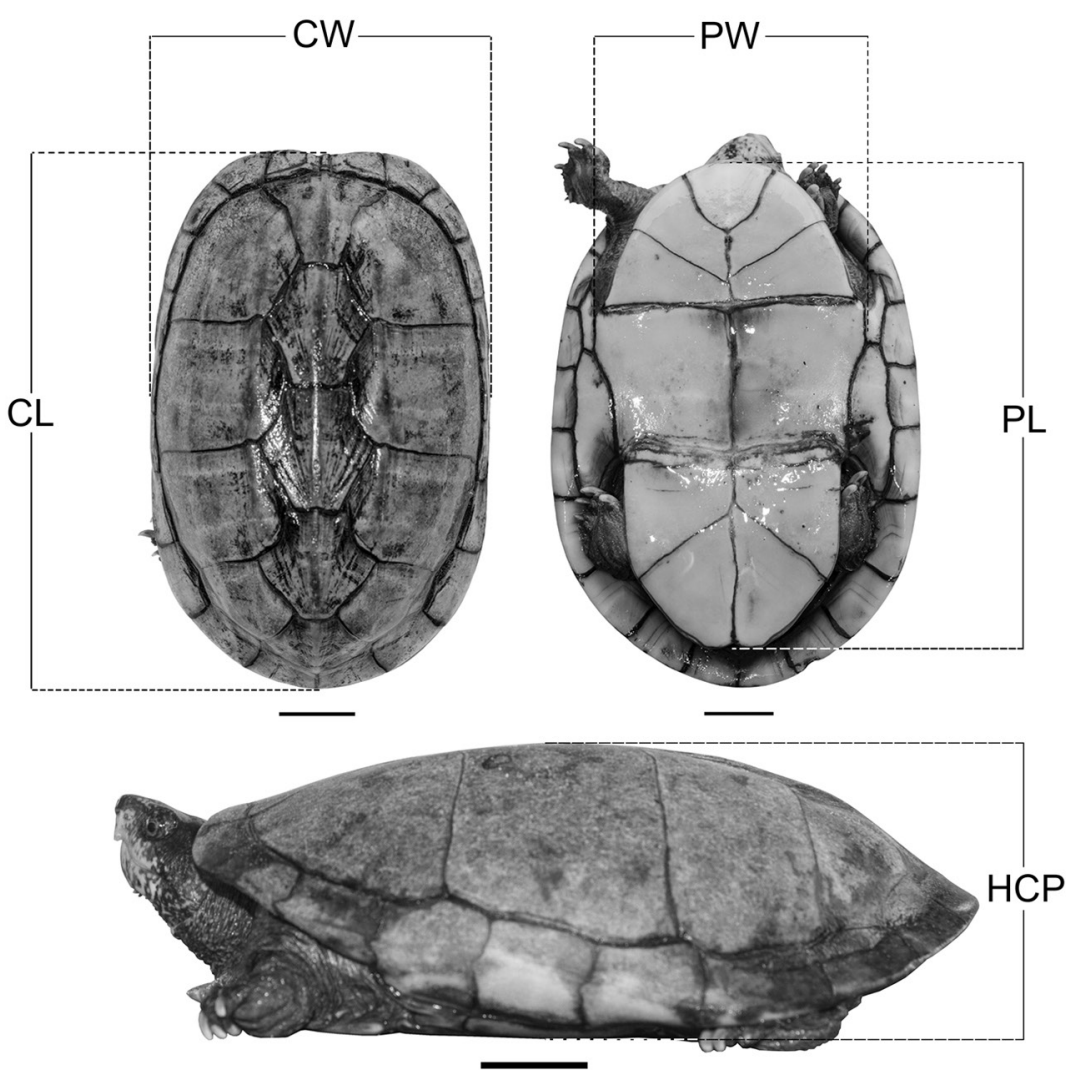

Fig. 2. Corporal biometrics in Kinosternon scorpioides scorpioides ( $2 \mathrm{~cm}$ scale). CL: Rectilinear carapace length, straight line from the nuchal to the supracaudal shield. CW: Rectilinear carapace width, distance between the edges of the marginal shields. PL: Rectilinear plastron length, straight line from the gular shields to the anal junction. PW: Rectilinear plastron width, distance between the ends of the intersection line of the pectoral and abdominal shields. HCP: Shell height, distance between the vertebral shields from the carapace to the plastron.

between the weight and the biometric measurements of adult animals. The normality of the variables for Pearson's Correlation was tested with the Shapiro Wilk test (Vieira, 1997). The correlation analyses between environmental variables and weight were performed using the GAM test (generalized additive model), due to the appearance of non-linear patterns in the data (Sothe, Camargo, Gerente, Rennó, \& Monteiro, 2017). All analyses were performed using the R software (R Core Team, 2018). PERMANOVA was made with the adonis function of the Vegan package (Oksanen et al., 2010). The t-test was performed with the t.test function, the Levene test with the levene.test function, the Shapiro test with the shapiro.test function, all from the basic $\mathrm{R}^{\circledR}$ package. The GAM model was made with the gam function of the gam package (Hastie, 2015) using a Bonferroni alpha of 0.025 to avoid type I error.

Analysis of geometric morphometry was performed on the MorphoJ software. Males and females were graphically ordered through the analysis of the principal components (PCA) (Klingenberg, 2011). Analysis of the canonical variation (CVA) and discriminant function was performed to test the differences. Thus, it was possible to visualize the variations by deformation grades in vector displacement (Valenzuela et al., 2004). 
A

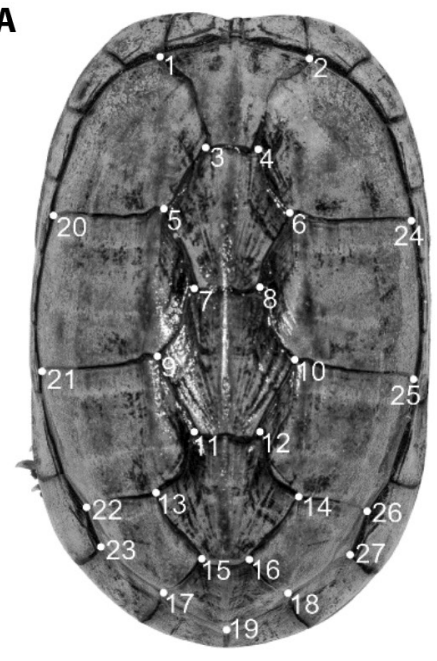

C

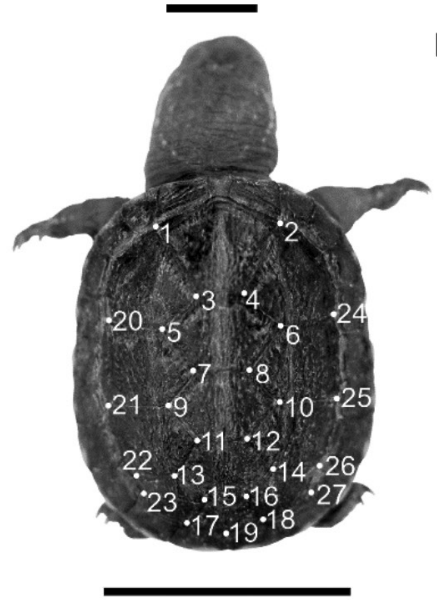

B

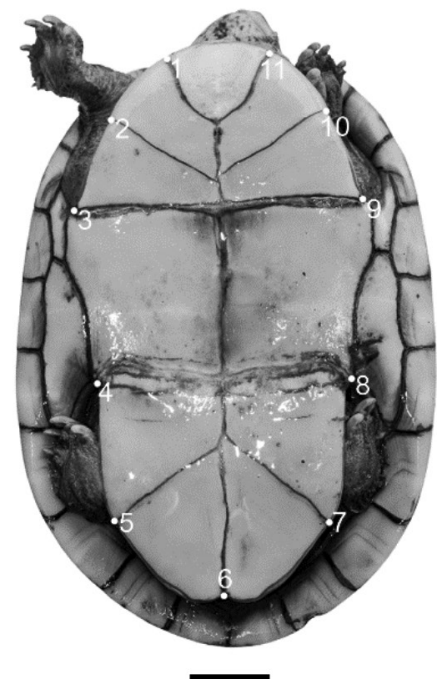

D

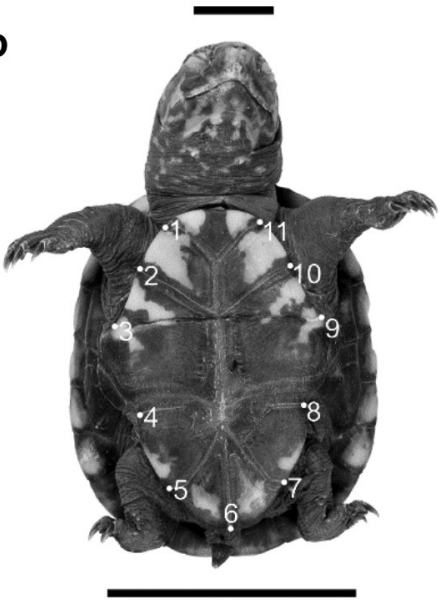

Fig. 3. Anatomical landmarks of Kinosternon scorpioides scorpioides $(2 \mathrm{~cm}$ scale). A. Carapace of adult turtle; B. Adult plastron; C. Carapace of hatchlings turtle; D. Hatchlings plastron.

\section{RESULTS}

No significant difference was observed among the biometric measurements observed between adult males and females, considering all variables together (PERMANOVA, pseudo-F $=3.488, \mathrm{R}^{2}=0.036, \mathrm{P}=0.082$ ). No significant difference between adult males and females was observed by Student-t on the length of the carapace $(\mathrm{T}=-0.559, \mathrm{df}=69.737$, $\mathrm{P}=0.577)$, width of the carapace $(\mathrm{T}=1.286$, df $=92.843, \mathrm{P}=0.201)$, width of the plastron $(\mathrm{T}$ $=1.950, \mathrm{df}=90.031, \mathrm{P}=0.054)$ and the weight
$(\mathrm{T}=2.110, \mathrm{df}=900.350, \mathrm{P}=0.037)$. However, a difference was observed between males and females on the length of the plastron $(\mathrm{T}=$ 2.286, $\mathrm{df}=92.252, \mathrm{P}=0.024)$ and the height of the shell $(\mathrm{T}=3.767, \mathrm{df}=92.384, \mathrm{P}=0.0001)$. Thus, adult females have longer plastrons and taller shells than males, despite the similar carapace measurements (Table 1).

Strong correlations were observed between weight and body measurements of adult females, which were greater than $90 \%$ for carapace and plastron length, and $80 \%$ for carapace and plastron width and shell height. 
TABLE 1

Biometric measurements (t-test) and weight of wild Kinosternon scorpioides scorpioides, adult male $(\mathrm{N}=34)$ and female $(\mathrm{N}=61)$, in Marajó Island, Pará, Brazil

\begin{tabular}{|c|c|c|c|c|c|c|c|}
\hline Variables & $\begin{array}{c}\text { Average } \pm \text { SD } \\
\text { Female }\end{array}$ & $\begin{array}{c}\text { Min - Max } \\
\text { F }\end{array}$ & Average \pm SD Male & $\begin{array}{c}\text { Min - Max } \\
\text { M }\end{array}$ & $\mathrm{T}$ & df & $\mathrm{P}$ \\
\hline $\mathrm{CL}(\mathrm{mm})$ & $144.37 \pm 14.37$ & $104.2-171.8$ & $146.07 \pm 14.03$ & $90.22-168.84$ & 0.56 & 69.74 & 0.577 \\
\hline $\mathrm{CW}(\mathrm{mm})$ & $92.50 \pm 9.77$ & $62.08-106.8$ & $90.52 \pm 5.18$ & $80.08-101.98$ & 1.29 & 92.84 & 0.201 \\
\hline $\mathrm{HCP}(\mathrm{mm})$ & $55.71 \pm 6.91$ & $35.6-68.9$ & $51.68 \pm 3.50$ & $43.64-58.8$ & 3.77 & 92.38 & $0.0001 *$ \\
\hline PL (mm) & $131.91 \pm 14.23$ & $90.98-154.4$ & $126.54 \pm 8.64$ & $101.68-149.34$ & 2.29 & 92.25 & $0.024 *$ \\
\hline $\mathrm{PW}(\mathrm{mm})$ & $65.37 \pm 7.0$ & $42.62-77.08$ & $63.03 \pm 4.66$ & $50.28-69.28$ & 1.95 & 90.03 & 0.054 \\
\hline Weight (g) & $401.07 \pm 106.36$ & $133-590$ & $362.77 \pm 69.92$ & $236-587$ & 2.11 & 90.35 & 0.037 \\
\hline
\end{tabular}

CL: carapace length; CW: carapace width; HCP: carapace height; PL: plastron length; PW: plastron width; SD: standard deviation; Min-Max F: minimum and maximum female values; Min-Max M: minimum and maximum male values; T: standardized $T$-score; df: degrees of freedom; P: the attained level of significance; *: P values that showed significant results of sexual dimorphism (t-test) using alpha $\mathrm{P}<0.025$.

TABLE 2

Pearson's correlation coefficient between weight and biometric measurements of wild Kinosternon scorpioides scorpioides, adult females $(\mathrm{N}=61)$ and males $(\mathrm{N}=34)$

\begin{tabular}{lccccccccccccc} 
& \multicolumn{2}{c}{ CL } & \multicolumn{2}{c}{ CW } & \multicolumn{2}{c}{ HCP } & \multicolumn{1}{c}{ PL } & \multicolumn{2}{c}{ PW } & \multicolumn{2}{c}{ Weight (g) } \\
& F & M & F & M & F & M & F & M & F & M & F & M \\
CL & 1.000 & 1.000 & & & & & & & & & \\
CW & 0.859 & 0.567 & 1.000 & 1.000 & & & & & & & \\
HCP & 0.838 & 0.383 & 0.787 & 0.314 & 1.000 & 1.000 & & & & & \\
PL & 0.937 & 0.528 & 0.863 & 0.726 & 0.845 & 0.441 & 1.000 & 1.000 & & & \\
PW & 0.874 & 0.390 & 0.840 & 0.717 & 0.817 & 0.379 & 0.905 & 0.660 & 1.000 & 1.000 & & \\
WEIGHT & 0.932 & 0.667 & 0.852 & 0.773 & 0.846 & 0.458 & 0.931 & 0.778 & 0.849 & 0.555 & 1.000 & 1.000 \\
\hline
\end{tabular}

CL: carapace length, CW: carapace width, HCP: carapace height, PL: plastron length, PW: plastron width.

Males also showed strong correlations between weight and body measurements, with carapace width and plastron length greater than $70 \%$, followed by carapace length greater than 60 $\%$, plastron width greater than $50 \%$ and shell height at $40 \%$ (Table 2).

Although there are visual trends, there was no relationship in adult female's weight considering rainfall increased (Explained deviance $=12.5 \%, \mathrm{R}^{2}(\operatorname{adj})=0.08, \mathrm{~F}=1.922$, edf $=3$, Ref.df $=3.37, \mathrm{P}=0.123$, Fig. $4 \mathrm{~A}$ ), as weight and temperature in males (Explained deviance $=17.7 \%, \mathrm{R}^{2}(\operatorname{adj})=0.128, \mathrm{~F}=2.609$, edf $=2$, Ref.df $=2.161, P=0.077$, Fig. 4B).

Geometric morphometry results showed an overlap of the anatomical landmarks in the principal component analysis (PCA) of the carapace of adult K. s. scorpioides, despite the trend in the differentiation between the sexes. Males were more distributed within the PC2 negative values, while females were distributed between PC1 negative values and PC2 positive values (Fig. 5A). PC1 explained $38.88 \%$ (Eigenvalues $=0.001)$ of the variation and the PC2 explained $28.13 \%$ (Eigenvalues $=0.0007)$. The greatest variation within the sample occurred at landmarks 17 and 18, these points are left-posterior and right to the fifth vertebral shield, respectively, and landmark 19 located caudally to the fifth vertebral shield (Fig. 3A). The canonical variation analysis (CVA) showed the significant 

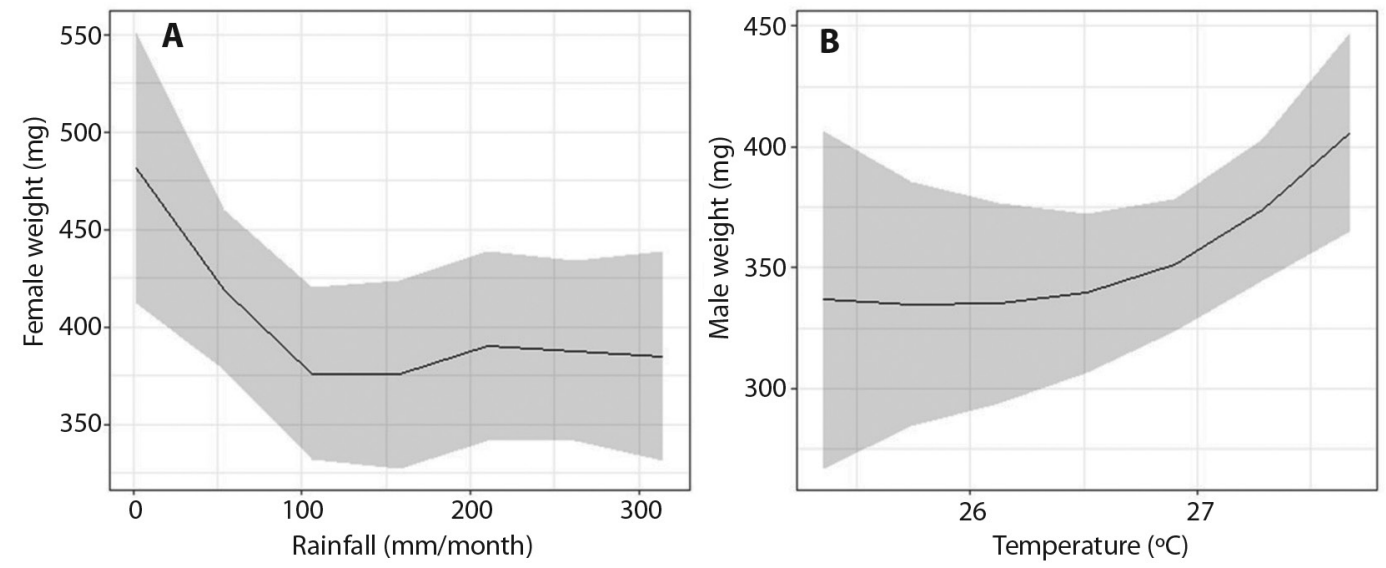

Fig. 4. Analysis of the correlation between the weight of adult Kinosternon scorpioides scorpioides, A. Females and B. Males and the environmental variables (rainfall and temperature) in Marajó island, Brazil.

difference (Mahalonobis $\mathrm{P}<0.001$, Procrustes $\mathrm{P}=0.0002$ ) between the carapaces of adult males and females (Fig. 5B). The discriminant function analysis also showed a significant difference between the sexes of adults $(\mathrm{P}<0.001)$. The graphical reconstruction of the PCA indicated a difference between the shields of the carapace of the females, which are larger than the males. This aspect makes the carapace of females rounded, while the males had an oval shape (Fig. 5C).

The plastron analysis of PCA of the adults showed that there is no separation between the sexes of scorpion mud turtle, as both are distributed in the two main axes (Fig. 5D). PC1 explained $34.94 \%$ (Eigenvalues $=0.0003$ ) of the variation and the PC2 explained $20.95 \%$ (Eigenvalues $=0.0002)$. The greatest variation within the sample occurred in landmarks 7, 8 and 9. Located on the left lateral portion of the plastron (Fig. 3B), on the left side of the intersection of the pectoral and abdominal shields (landmark 9), abdominal and femoral shields (landmark 8), and femoral and anal (landmarks 7). However, analyses of CVA (Fig. 5E) (Mahalonobis $\mathrm{P}<0.0001$, Procrustes $\mathrm{P}=$ $0.0002)$ and discriminant function were significant $(\mathrm{P}<0.001)$. The graphical reconstruction of the PCA showed the distinction between the sexes (Fig. 5F).
PCA analysis of the carapace of hatchlings $K$. s. scorpioides turtles showed an overlap of anatomical landmarks, despite the trend in differentiating between the sexes. Males were more distributed within the $\mathrm{PC} 1$ and $\mathrm{PC} 2$ positive values; while females were distributed between positive and negative PC1 and negative PC2 values (Fig. 5G). PC1 explained $30.08 \%$ (Eigenvalues $=0.001)$ of the variation and the PC2 explained $24.53 \%$ (Eigenvalues $=0.0008)$. The greatest variation within the sample occurred in landmarks 3 and 4, located caudally to the first vertebral shield (Fig. 3C). However, in the canonical variation analysis (CVA), it was not possible to find a significant difference (Mahalonobis $\mathrm{P}=0.022$, Procrustes $\mathrm{P}=0.074$ ) between the carapaces of male and female hatchlings (Fig. 5H). Furthermore, the discriminant function analysis did not show a separation between the sexes $(\mathrm{P}>0.001)$. Graphical reconstruction of the PCA showed the similarity between the carapace of males and females (Fig. 5I).

The plastron analysis of PCA of the hatchlings showed that the dispersion of male and female was homogeneous between values of PC1 and PC2. PC1 explained 36.51\% (Eigenvalues $=0.0005)$ of the variation and $\mathrm{PC} 2$ explained $17.52 \%($ Eigenvalues $=0.0003)$. The greatest variation within the sample occurred 
A

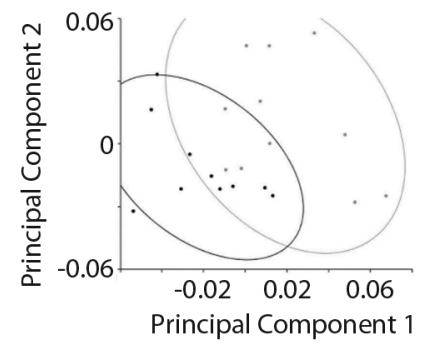

D

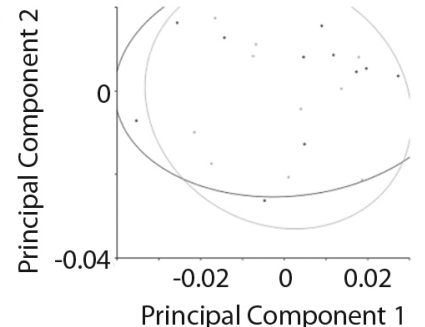

G

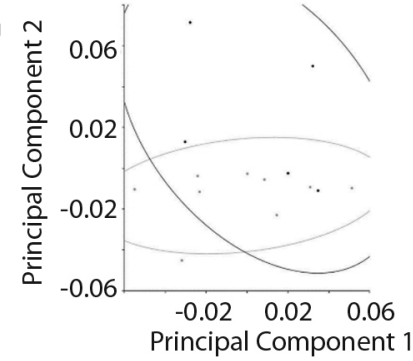

J

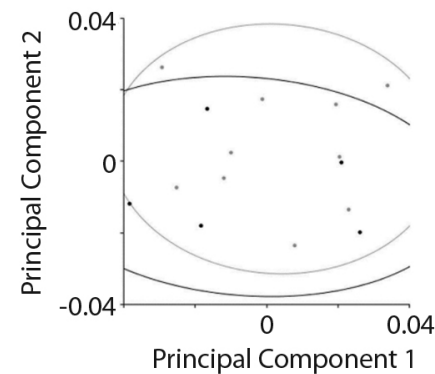

B

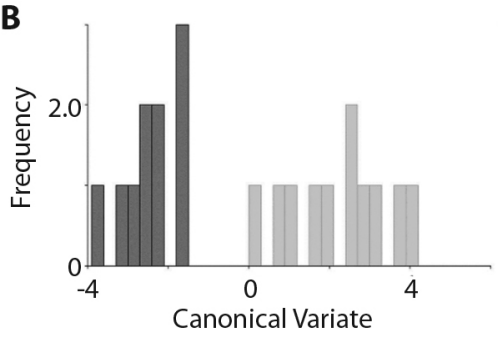

E

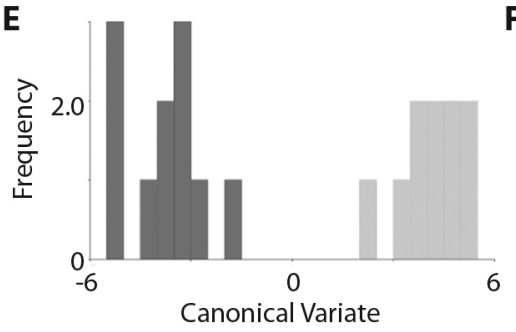

H

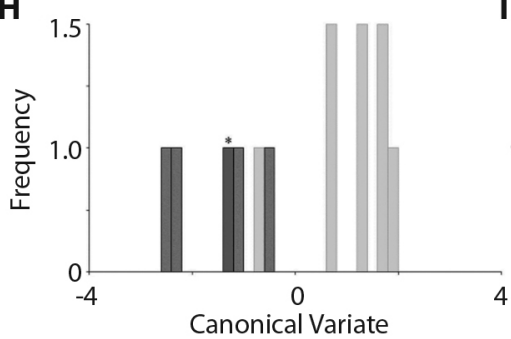

K

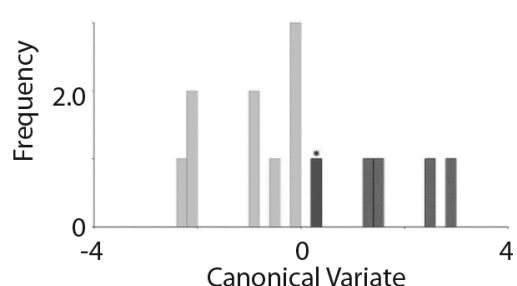

I
C
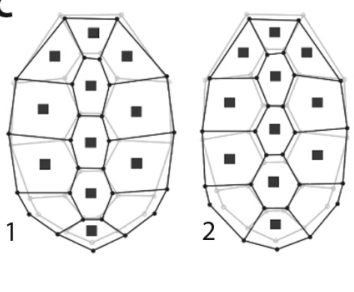

F

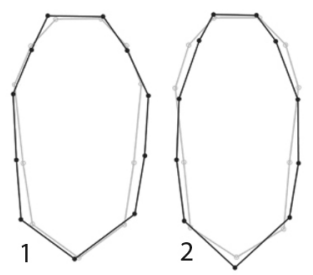

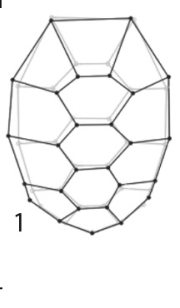

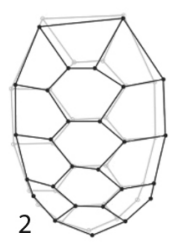

L
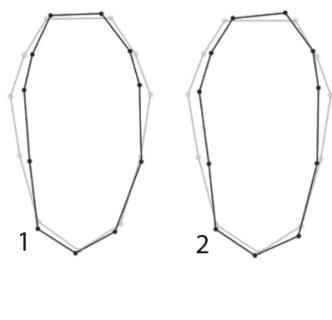

Fig. 5. Analysis of geometric morphometry of the Kinosternon scorpioides scorpioides. Adult individuals are represented from A to F. A. Dispersion of the anatomical landmarks of the carapace; B. Analysis of CVA, 10 000-times amplified of the carapace of adult. C. Graphical reconstruction of the carapace; D. Dispersion of the anatomical landmarks of the plastron; E. Analysis of CVA, amplified 10000 times, of the plastron; F. Graphical reconstruction of the plastron. The same analyzes are observed on the hatchlings individuals from $\mathbf{G}$ to $\mathbf{L}$, respectively. * indicates overlapping between females and males, black lines: shape of the carapace, gray lines: consensus configurations; gray dots or bars: female, black dots or bars: male; 1: females and 2: males. 
TABLE 3

Biometric measurements of hatchlings in captivity of Kinosternon scorpioides scorpioides, and significance test between males $(\mathrm{N}=4)$ and females $(\mathrm{N}=17)$

\begin{tabular}{lccccccc}
\multicolumn{1}{c}{ Variables } & Average \pm SD & Min-Max & Average \pm SD M & Min-Max & T & df & $P$ \\
CL $(\mathrm{mm})$ & $29.11 \pm 2.25$ & $24.72-33.30$ & $27.15 \pm 5.55$ & $19.500-32.600$ & 0.69 & 3.24 & 0.533 \\
CW $(\mathrm{mm})$ & $19.68 \pm 3.78$ & $11.00-28.20$ & $21.27 \pm 4.67$ & $17.880-28.100$ & -0.63 & 3.97 & 0.561 \\
HCP $(\mathrm{mm})$ & $12.18 \pm 2.10$ & $9.40-17.20$ & $10.87 \pm 2.02$ & $8.500-13.120$ & 1.16 & 4.66 & 0.301 \\
PL $(\mathrm{mm})$ & $23.33 \pm 3.86$ & $10.00-27.96$ & $25.32 \pm 1.92$ & $23.500-27.660$ & -1.48 & 9.74 & 0.170 \\
PW $(\mathrm{mm})$ & $14.02 \pm 0.90$ & $13.00-15.90$ & $15.81 \pm 3.15$ & $13.740-20.500$ & -1.8 & 9.74 & 0.169 \\
\hline
\end{tabular}

F: female; M: male; CL: carapace length; CW: carapace width; HCP: carapace height; PL: plastron length; PW: plastron width; SD: standard deviation; Min-Max F: minimum and maximum female values; Min-Max M: minimum and maximum male values; T: standardized $T$-score; df: degrees of freedom; P: the attained level of significance.

in landmarks 3 and 9, located on the right and left laterolateral portion of the plastron, respectively (Fig. 3D). It was not possible to observe a separation of the sexes of scorpion mud turtle (Fig. 5J); neither the CVA analysis (Fig. 5K) (Mahalonobis $\mathrm{P}=0.006$, Procrustes $\mathrm{P}$ $=0.511)$ nor the discriminant function were not significant $(\mathrm{P}>0.001)$. The similarity between the plastron of males and females (Fig. 5L) was possible to observe in the graphical reconstruction of the PCA.

Histological sections of the gonads of the hatchlings $K$. s. scorpioides showed the cortical region of the ovaries with primordial follicles, well delimited by the connective tissue stroma. The testicles were covered by the tunica albuginea, and interstitial cells were observed in the stroma between the seminiferous tubules, which contained the spermatogonia.

There was no significant difference in biometric values observed with male and female hatchlings, considering all variables together (PERMANOVA, pseudo- $\mathrm{f}=1.116, \mathrm{R}^{2}=0.055$, $\mathrm{P}=0.369)$ and in any measure tested with the t-test (Table 3).

\section{DISCUSSION}

The identification of dimorphism between the sexes of turtles, through corporal morphometry, gives valuable tools for application in taxonomy and management of species. This study was the first to use morphometric analysis in a natural population of $K$. s. scorpioides on Marajó Island, Pará, Brazil.

The results indicated that there is sexual dimorphism in wild adult scorpion mud turtles. Measures related to plastron and height were more evident in females. Although the carapace has biometric similarity between the sexes, the geometric shape observed in the PCA graphical representation demonstrated that this structure is more elongated in males, when compared to the rounded aspect of the female. Variations in body size according to the geographical location was observed, specifically in $K$. scorpioides natural populations, where males may have greater or smaller carapace lengths than females (Acuña-Mesén \& Arturo, 1994; Márquez, 1995; Iverson, 2010; Berry \& Iverson, 2011; Moura et al., 2015). Furthermore, females of this species have a more curved body shape, and a larger plastron than males (Berry \& Iverson, 2011). Such body characteristics in Kinosternidae, according to Berry and Shine (1980) would be related to sexual behavior strategies, where males of the same size or larger than females impose copulation, instead of being chosen through courtship. In addition, it is possible that population genetic variability influences morphological pattern of this group.

It is known that the $K$. s. scorpioides has a seasonal reproductive period, which starts in late December, with the mating peak in late March and early April, and laying between 
late June and early August, concentrated in the rainiest season on Marajó Island, where there is more food supply (Costa et al., 2017). This period is followed by the dormancy behavior of the animals during the dry season (Cristo et al., 2017). In the present study, weight gain in females was not statistically significant correlated with the reduction in rainfall, and in males with the increase in temperature. However, it is known that any minimal change in environmental factors could affect the growth and reproduction of the turtles (Lovich, Ennen, Agha, \& Gibbons, 2018). Furthermore, the result of this work demonstrated a biological trend that, in the wild, adult females and males showed weight gain at least until the rainy period, thus storing energy reserves for both reproduction and the dormancy season. As observed in the literature, Homopus signatus signatus (Loehr, Hofmeyr, \& Henen, 2007) and Chelonia mydas (Stubbs, Marn, Vanderklift, Fossette, \& Mitchell, 2020), the environmental changes (e.g., temperature and rainfall) have a strong impact on the growth and reproduction of turtles, being associated with the availability of food. Based on this mechanism, reproduction in wild animals occurs in the period of the year most propitious for the survival of parent and young, and in reptiles the environmental factors may directly trigger physiological of this process (Kuchling, 1999).

Concerning hatchlings, ovarian histology was characterized by the presence of primordial follicles, and the testicles by the observation of the seminiferous tubules. Hatchling biometry was similar to the results observed by Costa et al. (2017). However, there was no sexual difference in relation to body morphometry, despite the tendency to differentiate in the PCA analysis of the carapace. Possibly, the small sample number of males $(\mathrm{N}=5)$ used in this work could have contributed to the non-morphometric differentiation, which was also a negative factor in the analyses of C. mydas (Sönmez et al., 2019). Even though, the sexual identification of Caretta caretta hatchlings was also only possible through the histological observation of the gonads, there was no difference in geometric morphometry ( $\mathrm{N}=174$, Mendes, 2017). In contrast, in hatchlings of Podocnemis expansa $(\mathrm{N}=230)$ and Chrysemys picta $(\mathrm{N}=$ 87 ), sexed by radioimmunoassay or by gonadal macroscopic observation, it was possible to differentiate sexual dimorphism using geometric morphometry (Valenzuela et al., 2004).

The biological significance of the morphological difference in adult animals, could be related to the reproductive behavior of the species. In addition, the results of this work reinforce the idea that environmental events are the triggers that support the reproductive strategy of these animals. As the degradation of the environment and large scale hunting are the greatest threats to the species (Berry \& Iverson, 2011; Cristo et al., 2017), its reproductive strategy suggests that it would not be adapted to severe anthropogenic changes in the ecosystem. Thus, the data obtained in this work provide information for a better understanding in situ and ex situ management of the species.

Ethical statement: authors declare that they all agree with this publication and made significant contributions; that there is no conflict of interest of any kind; and that we followed all pertinent ethical and legal procedures and requirements. All financial sources are fully and clearly stated in the acknowledgements section. A signed document has been filed in the journal archives.

\section{ACKNOWLEDGMENTS}

Our thanks to Embrapa Amazônia Oriental - Campus Experimental Emerson Salimos, and the Guajarás farm for the logistical support. Joilson Silva da Silva and Brenda Stefany dos Santos Braga thank the Coordenação de Aperfeiçoamento de Pessoal de Nível Superior (CAPES) and Postgraduate Program in Biodiversity and Conservation of the Universidade Federal do Pará for master's scholarship. Juliane da Silva Costa and Brenda Stefany dos Santos Braga thank CAPES and Post-Graduate Program in Animal Science of the Universidade Federal do Pará for doctorate scholarship. 
The authors thank Michele Singh (Caribbean Agricultural Research and Development Institute), for assistance with the comments, and Martín Roberto Del Valle Alvarez for translating the summary into Spanish.

\section{RESUMEN}

\section{Dimorfismo sexual de la tortuga Kinosternon scorpioides (Testudines: Kinosternidae) en la isla de Marajó, Amazonia brasileña}

Introducción: La morfometría es una técnica eficiente y de bajo costo, utilizada en estudios de dimorfismo sexual en tortugas, mediante el marcado de puntos anatómicos. Este grupo incluye Kinosternon scorpioides scorpioides, con una amplia variedad fenotípica, dependiendo del área en la que se encuentra presente. Objetivo: Este estudio tuvo como objetivo identificar la diferencia sexual entre $K$. s. scorpioides, adultos y juveniles, a través del análisis morfométrico; y verificar la relación entre las medidas de peso para adultos y los factores ambientales (temperatura y precipitación) en la isla de Marajó, Brasil. Métodos: La recolecta se realizó de marzo a septiembre de 2018, cubriendo tanto la temporada de lluvias (enero a julio) como la estación seca (agosto a diciembre). Para el análisis biométrico, se utilizaron 95 animales adultos y 21 crías, en los que se midió la longitud y el ancho del caparazón y el plastrón, la altura del casco y el peso en adultos. Para la morfometría geométrica, se utilizaron 21 adultos y 13 juveniles, en los que se identificaron 27 coordenadas de puntos de referencia anatómicos en el caparazón y 11 en el plastrón. Los individuos recién eclosionados fueron sexados por histología de rutina, que permite identificar ovarios y testículos. Resultados: Los datos analizados mostraron que existe dimorfismo sexual en adultos. El plastrón y la altura fueron mayores en las hembras, que tenían un caparazón más redondeado que los machos. Esta característica puede estar relacionada con la estrategia sexual de la especie, donde los machos imponen la cópula. En los juveniles recién eclosionados fue posible identificar histológicamente los ovarios y los testículos, pero no hubo diferencias sexuales en relación con la morfometría corporal, a pesar de la tendencia a diferenciarse en el análisis de PCA de caparazón. Conclusiones: El dimorfismo sexual en $K$. s. scorpioides puede desempeñar un papel importante en su comportamiento reproductivo, que ocurre en sincronía con los eventos ambientales. Este hecho sugiere que las estrategias reproductivas de esta especie se verían gravemente afectadas por los cambios en el ecosistema.

Palabras clave: biometría; diferencia sexual; morfometría geométrica; tortuga casquito; quelonio.

\section{REFERENCES}

Acuña-Mesén, R.A., \& Arturo, R. (1994). Variación morfométrica y características ecológicas del hábitat de la tortuga candado Kinosternon scorpioides en Costa Rica (Chelonia, Kinosternidae). Revista Brasileira de Biologia, 54, 537-547.

Anderson, M.J. (2005). Permutational multivariate analysis of variance. Department of Statistics, University of Auckland, Auckland, 26, 32-46.

Barreto, L., Lima, L.C., \& Barbosa, S. (2009). Observations on the ecology of Trachemys adiutrix and Kinosternon scorpioides on Curupu Island, Brazil. Herpetological Review, 40(3), 283-286.

Berry, J.F., \& Iverson, J.B. (2011) Kinosternon scorpioides (Linnaeus 1766)-Scorpion Mud Turtle. In A.G.F. Rhodin, P.C.H. Pritchard, P.P. Van Dijk, R.A. Saumure, K.A. Buhlman, J.B. Iverson, \& R.A. Mittermeier (Eds.), Conservation Biology of Freshwater Turtles and Tortoises: A Compilation Project of the IUCN/SSC Tortoise and Freshwater Turtle Specialist Group (pp. 063.1-063.15). New York, US: Chelonian Research Monographs.

Berry, J.F., \& Shine, R. (1980). Sexual size dimorphism and sexual selection in turtles (Order Testudines). Oecologia, 44(2), 185-191.

Castro, A.B. (2006). Biologia reprodutiva e crescimento do muçuã Kinosternon scorpioides (Linnaeus, 1776) em cativeiro (Master's dissertation). Universidade Federal do Pará, Belém, Brasil. Retrieved from http:// repositorio.ufpa.br/jspui/handle/2011/5547

Costa, H.C., \& Bérnils, R.S. (2018). Répteis do Brasil e suas Unidades Federativas: Lista de espécies. Herpetologia Brasileira, 7(1), 11-57.

Costa, J.S., Matos, A.S., Marques, L.C., Silva, C.S., Figueiró, M.R., Sales, R.L., ... Marques, J.R.F. (2017). Características produtivas de Kinosternon scorpioides nas fases de acasalamento, postura e eclosão, criados em cativeiro na Amazônia. Archivos de Zootecnia, 66, 387-394.

Cristo, S.S., Baía-Júnior, P.C., Silva, J.S., Marques, J.R.F., \& Guimarães, D.A.A. (2017). The trade of Kinosternon scorpioides on Marajó Island, Brazilian Amazon: From hunting to consumption. Herpetological Journal, 27, 361-367.

Depecker, M., Berge, C., Penin, X., \& Renous, S. (2006). Geometric morphometrics of the shoulder girdle in extant turtles (Chelonii). Journal of Anatomy, 208, $35-45$.

Domingues, M.K. (2015). Testando a existência de dimorfismo sexual na fase juvenil da tartaruga-verde 
(Chelonia mydas Linnaeus, 1758) através da morfometria geométrica [Monograph]. Retrieved from https://acervodigital.ufpr.br/handle/1884/41666

Ewert, M.A., \& Nelson, C.E. (1991). Sex Determination in Turtles: Diverse Patterns and Some Possible Adaptive Values. American Society of Ichthyologists and Herpetologists, 1, 50-69.

Ferrara, C.R., Bernardes, V.C.D., Waldez, F., Vogt, R.C., Bernhard, R., Balestra, R.A.M., \& Campos, J.V. (2016). História natural e biologia dos quelônios amazônicos. In R.A.M. Balestra (Ed.), Manejo conservacionista e monitoramento populacional de quelônios amazônicos (pp. 15-28). Brasília, Brasil: Instituto Brasileiro do Meio Ambiente e dos Recursos Naturais Renováveis.

Ferreira-Júnior, P.D. (2009). Efeitos de fatores ambientais na reprodução de tartarugas. Acta Amazonica, 39, 319-334.

Ferreira-Júnior, P.D., Treichel, R.L., Scaramussa, T.L., \& Scalfoni, J.T. (2011). Morphometric pattern in Caretta caretta (Linnaeus, 1758)(Cheloniidae) hatchlings from nests with different embryo development rates. Brazilian Journal of Biology, 71, 151-156.

Haas, T.C. (2011). Guide to the "Unbend Specimens" module in tpsUutil. Retrieved from http://www. academia.edu/498700/Guide_to_the_Unbend_specimens_module_in_tpsUtil

Hastie, T. (2015). Package 'gam' (Version 1.2, R Package). Retrieved from http://cran.r-project.org/web/packages/gam/gam.pdf

Iverson, J.B. (2010). Reproduction in the red-cheeked mud turtle (Kinosternon scorpioides cruentatum) in southeastern Mexico and Belize, with comparisons across the species range. Chelonian Conservation and Biology, 9, 250-261.

Klingenberg, C.P. (2011). Morphoj: an integrated software package for geometric morphometrics. Molecular Ecology Resources, 11, 353-357.

Kuchling, G. (1999). The Reproductive Biology of the Chelonia. Berlin, Germany: Springer-Verlag.

Loehr, V.J.T., Hofmeyr, M.D., \& Henen, B.T. (2007). Growing and shrinking in the smallest tortoise, Homopus signatus signatus: the importance of rain. Oecologia, 153,479-488.

Lovich, J.E., Ennen, J.R., Agha, M., \& Gibbons, W.H. (2018). Where Have All the Turtles Gone, and Why Does It Matter? BioScience, 68, 771-781.

Lyra, M.L., Hatadani, L.M., Azeredo-Espin, A.M.L., \& Klaczko, L.B. (2010). Wing morphometry as a tool for correct identification of primary and secondary new world screwworm fly. Bulletin of Entomological Research, 100, 19-26.

Márquez, C. (1995). Historia natural y dimorfismo sexual de la tortuga Kinosternon scorpioides en Palo Verde, Costa Rica. Revista Ecológica Latino Americana, 2, 37-44.

Mendes, S.S. (2017). Morfometria geométrica e histologia: ferramentas complementares na estimativa do sexo de filhotes da tartaruga marinha Caretta Caretta (Linnaeus, 1758) (Testudines, Cheloniidae) dos Estados da Bahia e do Espírito Santo (Doctoral thesis). Universidade de Juiz de Fora, Juiz de Fora, Brasil. Retrieved from https://repositorio.ufjf.br/jspui/ handle/ufjf/5653

Monteiro, L.R., \& Reis, S.F. (1999). Princípios de morfometria geométrica. São Paulo, Brazil: Holos.

Moraes, B.C., Costa, J.M.N., Costa, A.C.L., \& Costa, M.H. (2005). Variação espacial e temporal da precipitação no Estado do Pará. Acta Amazonica, 35, 207-214.

Moura, C., Moura, G., Chaves, L., Muniz, S., Veja, E., \& Júnior, V. (2015). Demography, sex ratio, and sexual dimorphism of testudines in Araripe bioregion, Ceará, Northeastern Brazil. North-Western Journal of Zoology, 11, 204-212.

Oksanen, J., Blanchet, F.G., Kindt, R., Legendre, P., O'hara, R.B., Simpson, G.L., ... Wagner, H. (2010). Vegan: community ecology package (Version 1.17-4, $\mathrm{R}$ package). Retrieved from http://cran.r-project.org/ web/packages/vegan/index.html

R Core Team. (2018). R: A Language and Environment for Statistical Computing. R Foundation for Statistical Computing, Vienna, Austria. Retrieved from http:// www.R-project.org

Rhodin, A.G.J., Iverson, J.B., Bour, R., Fritz, U., Georges, A., Shaffer, H.B., \& Van Dijk, P.P. (2017). Turtles of the World: Annotated Checklist and Atlas of Taxonomy, Synonymy, Distribution, and Conservation Status. In A.G.J. Rhodin et al. (Eds.), Conservation Biology of Freshwater Turtles and Tortoises: A Compilation Project of the IUCN/SSC Tortoise and Freshwater Turtle Specialist Group ( $8^{\text {th }}$ ed., pp. 1-192). New York, US: Chelonian Research Monographs.

Rueda-Almonacid, J.V., Carr, J.L., Mittermeier, R.A., Rodríguez-Mahecha, J.V., Mast, R.B., Vogt, R.C., ... \& Mittermeier, C.G. (2007). Las tortugas y los cocodrilianos de los países andinos del trópico: Manual para su identificación (pp. 88-90). Bogotá, Colombia: Editorial Panamericana, Formas e Impresos.

Sönmez, B., Bağda, E., Candan, O., \& Yilmaz, H.E. (2019). Sex determination in green turtle hatchlings: geometric morphometry and molecular sex markers. Natural and Engineering Sciences, 4(1), 42-54. 
Sothe, C., Camargo, E.C.G., Gerente, J., Rennó, C.D., \& Monteiro, A.M.V. (2017). Uso de modelo aditivo generalizado para análise espacial da suscetibilidade a movimentos de massa. Revista do Departamento de Geografia, 34, 68-81.

Souza, F.L. (2004). Uma revisão sobre padrões de atividade, reprodução e alimentação de cágados brasileiros. Phyllomedusa, 3(1), 15-27.

Stubbs, J.L., Marn, N., Vanderklift, M.A., Fossette, S., \& Mitchell, N.J. (2020). Simulated growth and reproduction of green turtles (Chelonia mydas) under climate change and marine heatwave scenarios. Ecological Modelling, 431, 109-185.

Valenzuela, N., Adams, D.C., Bowden, R.M., \& Gauger, A.C. (2004). Geometric morphometric sex estimation for hatchling turtles: a powerful alternative for detecting subtle sexual shape dimorphism. Copeia, $4,735-742$.

Van Der Molen, S., Martínez-Abadía, N., \& González, R. (2007). Introducción a la Morfometría Geométrica:
Manual del Curso Teórico-Práctico. Barcelona, España: Universidad de Barcelona.

Viana, D.C., Santos, A.C., \& Antunes, R.L.S. (2015). New record of Kinosternon scorpioides in Brazil increases its geo distribution. Revista Brasileira de Medicina Veterinária, 37(4), 386-388.

Vieira, S. (1997). Introdução à bioestatística. Rio de Janeiro, Brasil: Elsevier.

Vogt, R.C. (2008). Tartarugas da Amazônia. Lima, Peru: Gráfica Biblos.

Vogt, R.C., Fagundes, C.K., Bataus, Y.S.L., Balestra, R.A.M., Batista, F.R.W., Uhlig, V.M., ... \& Luz, V.L.F. (2015). Avaliação do Risco de Extinção de Kinosternon scorpioides (Linnaeus, 1766) no Brasil. Processo de avaliação do risco de extinção da fauna brasileira, Instituto Chico Mendes de Conservação da Biodiversidade (ICMBio). Retrieved from http:// www.icmbio.gov.br/portal/biodiversidade/fauna-brasileira/estado-de-conservacao/7407-repteis-kinosternon-scorpioides-mucua.html 